Kaygl, 18(II)/2019: 289-303.

Research Article | Araştırma Makalesi

Makale Geliş | Received: 01.10.2018

Makale Kabul | Accepted: 05.04.2019

Yayın Tarihi | Publication Date: 30.09.2019

DOI: $10.20981 /$ kaygi.612491

Tomasz JARYMOWICZ

$\mathrm{PhD}$.

The Arctic University of Norway, Norway.

ORCID: 0000-0003-2148-5812

arymowicz@uit.no

\title{
Comprehensive Doctrines in the Public Sphere - A Case for Politicization
}

\section{Abstract}

The problem with religious reasons is not whether they should be present in the public sphere but how they should be present. Political theorists such as Jeremy Waldron, Juergen Habermas, and Christina Lafont have favored two approaches to making religion legitimate in the public sphere. They have either tried to work out the conditions under which religious reasons can contribute to public sphere in a fruitful way or they have drawn attention to the moral content of religious principles. However, I argue that the latter approach relies too heavily on the propositional content of religious arguments to the detriment of investigating how they are politicized in the public sphere. It is my conviction that without looking at how given religious morality is politicized, a false moral consensus is manufactured, which given the motivational pull of religion can be dangerous. Furthermore, the article makes a case for a more realistic idea of a public sphere where other comprehensive doctrines such as feminism or economism are taken into account as well. Moreover, the evaluation of religious reasons should include their relationship to a given background political culture, which will increase a critical edge of a political theory.

Keywords: Habermas, Religious Reasons, Public Sphere, Deliberative Democracy. 
Religious arguments have become a paradigmatic example of a comprehensive doctrine in broadly understood public sphere. Political theorists have been targeting religion and religious citizens as the main source of a possible breach of civility and dangerous instability in a liberal state. Nevertheless, there seems to be a growing consensus (e.g. Habermas: 2006; Lafont: 2009; March: 2013) that religious arguments should be included in the public sphere and the task of political philosophy have been to normatively specify the conditions under which religious arguments can be brought to the deliberative table.

Political theorists have started the task of legitimizing the place of religious reasons in the public sphere in two ways. On the one hand, they work on the conditions that need to be met by religious citizens to fulfill the duty of civility during deliberation. On the other hand, they try to show all the positive contributions that religion makes in the public sphere. Those two approaches are by no means mutually exclusive; rather they both reinforce each other. They present some version of ethics of citizenship for religious contribution, however, they also foreground the content of religious arguments that adds to their legitimacy in the public sphere. Jürgen Habermas (2003) and Jeremy Waldron (2012) mention unconditional nature of religion that can be invoked to fight against absolute evil such as slavery or torture. Christopher Eberle (2009) points to the content of religion to claim that peaceful religious citizens cannot disrespect other citizens. Lucas Swaine (2009) invokes examples of religious citizens as Samaritans and finally Darren R. Walhoflof (2013) points to the inherent political nature of religion to show that it cannot be dismissed from taking part in public deliberation.

However, it seems that all of those attempts just mentioned rely excessively on propositional content of religious contribution to the public sphere to make them legitimate, which in turn diminishes the importance of the problem of how this content should actually be politicized in the public sphere. Moreover, it seems that ignoring other comprehensive doctrines such as feminism or economism active in the public sphere not only diminishes the critical edge of political theory but also presents an 
inadequate description of the public sphere, which in turn amplifies the problem of in what way comprehensive doctrines should be politicized in the public sphere.

While I do not disparage how religious reasons enrich or contribute to the public sphere in a positive way nor do I diminish the importance of the propositional content of religion, this paper calls attention to how the focus on content of religious reasons takes attention away from the way they actually are and should be politicized. In other words, those approaches sidestep the problem of politicization. Furthermore, I also argue that singling out religious arguments as the only problematic comprehensive doctrine present in the public sphere exacerbate the problem of politicization since it fails to offer the plausible version of the public sphere. If we see that the lack of accessibility of comprehensive arguments is relative to a given background culture and that the citizens can have both religious and secular arguments with varying degree of motivational pull, then we should redirect our attention from the content of comprehensive doctrines including religion to how they take part in the public deliberation.

The paper will proceed as follows. In the first section, I will concentrate on various ways in which the content of religious claims actually is taken to diminish the challenge of how if at all they should be politicized. In the second section, I focus on how an implausible picture of a public sphere with religious and secular citizens speaking totally different languages only exacerbate the problem of how religious claim should take part in deliberation.

\section{Political theorists to the rescue of religion}

The aim of the present section is to show how particular good contributions of religion to the public sphere as well as its propositional content can replace the need to politicize them by manufacturing false consensus. Firstly, I will present the case of Eberle (2009), whose example of Agapic Pacifist and her beliefs explicitly replace politicization. Secondly, I will present the case of Swaine, (2009) who also explicitly uses the propositional content of religious arguments to show that their contribution should be valued in the public sphere. I will present how both Waldron (2012) and 
Habermas (2003) point to the moment of unconditionally in religion that accounts for its motivational power in the public sphere. According to them, this motivational power is needed at times of severe moral strife such as fight against torture. I will argue that given the political nature of the public sphere, all those examples reduce the need for politicization of religious arguments, which is dangerous given the motivational power of religion.

Let me start with Eberle's article Basic Human Worth and Religious Restraint (2009), which is a powerful critique of liberal requirement of offering only public reasons for supporting coercive laws. I am not interested here that much in the ethics of citizenship (cf. Talisse 2012) but more in how the content of Agapic Pacifist's doctrine makes its politicization redundant according to the author. Eberle's Agapic Pacifist has three main features:

First, she is led by what I shall call 'the Agapic Argument' to affirm the proposition that waging war is always morally prohibited. Second, the Agapic Pacifist is not just 'privately' against waging war and so unwilling to fight herself. Her convictions about the moral permissibility of waging war are no more and no less private than those of her ideological competitors in the just war and realist camps. Third, the Agapic Pacifist violates the DRR (the Doctrine of Religious Restraint). Since the Agapic Argument is a crucial basis for her conviction that waging war is never morally permissible, as well as for any vote she might cast in support of Amendment 28, and since the Agapic Pacifist is unaware of any plausible secular rationale for that measure, she reasonably believes that her secular compatriots have what they regard as no reason at all to support Amendment 28. (Eberle2009: 153-154).

What strikes me in this example is that the agenda of Agapic Pacifist is strictly moral and unconditional; Agapic Pacifist is not willing to compromise her beliefs in any possible manner. We might say that she violates the ideal of respect by relying ultimately on non-public reasons to coerce her fellow citizens into obedience but Eberle rejects this interpretation. He rejects the idea that Agapic Pacifist may disrespect her compatriots because she is opposed to the war precisely on account of her respect for other people's lives. This leads him to claim

Of all people, how could the Agapic Pacifist plausibly be regarded as disrespecting her compatriots? She might be rash, or foolhardy, or naïve, or 
cowardly, or fanatical. She is certainly misguided. But disrespectful of the worth of her compatriots? Incredible. (Eberle 2009: 160).

Consequently, it seems that the content of Agapic Pacifist's moral doctrine is supposed to do more job than Eberle is willing to admit. In other words, it is enough to evaluate the content of a moral doctrine of a given citizen to ascertain whether she or he will respect his or her compatriots in the public sphere. It is the only way to understand that respect and fanatism can go hand in hand.

Further, it seems also that although Eberle himself rejects this doctrine as unreasonable, part of respect that this doctrine bestows on Agapic Pacifist also comes from apparent accessibility of this doctrine. Obviously, non-religious citizens cannot relate to the religious justification given by Agapic Pacifist but they do understand what it means to be against war unconditionally and so it could seem to them a good idea without having to go into the details on what this idea is actually based on. This shows that sometimes citizens can give up on politicization and create a false consensus because a given doctrine looks good and the inaccessible justification does not really make any difference. It seems that foregrounding the content of a particular religious doctrine is often one of the ways in which religious contributions can be legitimized in the public sphere. In other words, religious people whose religious doctrines preach good will and universalist beliefs cannot go wrong in their attitudes. I submit that the universal values of equality and freedom are fairly uncontroversial and so everything comes down to how one interprets those values in a political process, which is the real problem in Agapic Pacifist's attitude towards other fellow citizens. ${ }^{1}$

We can see how the respect thesis functions even more clearly in Lucas Swaine's defense of heteronomous religious people in the public sphere. Swaine (2009: 189) argues that even if heteronomous, they can display a good ethics of citizenship towards others who do not share their own view. I do not argue with that but what is surprising is the empirical evidence that he gives to support his claims:

\footnotetext{
${ }^{1}$ This paper is not meant to criticize Eberle's idea of democratic procedure. Rather, I want to point to the problem that foregrounding the content of religion can effectively replace its politicization.
} 


\begin{abstract}
Many heteronomous people display empathy Indeed, many heteronomous people display empathy for those who are disenfranchised, marginalized, or impoverished, working to ameliorate the material conditions of the less fortunate and trying to involve them in social and political discussion. One finds examples of such people in convents, soup kitchens, and a variety of other milieux across liberal democracies. Heteronomous people lack the reflective disposition and attitude of revisability characteristic of their autonomous counterparts, but they can nevertheless enjoy the sort of 'enlarged thought' with which Kant was concerned, and are free to think from others' standpoints when it comes to knotty social and political problems. (Swaine 2009: 89)
\end{abstract}

The question is whether empathy, love, and the attitude of Good Samaritan is the right ideal in politics. Tove Pettersen (2012: 375) in her project of mature care claims that the unconditionality of Good Samaritan's care and altruism can disregard the issues of reciprocity and autonomy, which leads to the treatment of cared for persons as passive objects of paternalistic services. What this means for our discussion is that the abstract ideal of love and compassion is no guarantee of whether we treat the concrete other with respect, and therefore kitchen soups and empathy do not guarantee taking others' distinctive needs into account because love and empathy operate in the economy of sameness. Furthermore, as Hanna Arendt writes

For love, although it is one of the rarest occurrences in human lives, indeed possesses an unequaled power of self-revelation and an unequaled clarity of vision for the disclosure of who, precisely because it is unconcerned to the point of total unworldliness with what the loved person may be, with his qualities and shortcomings no less than with his achievements, failings, and transgressions. Love, by reason of its passion, destroys the in-between which relates us to and separates us from others. (Arendt 1998: 242).

Love is apolitical because it abstracts from everything that is different and focuses on what is the same. A good example here would be Catholicism's attitude towards gays and lesbians. The Church loves the human in each of them but condemns the acts, which is everything that is different. It shows that one thing is to love and quite another to respect one's normative agency. Finally, what we must bear in mind is that what is considered common humanity is always constructed based on a particular religious doctrine, so the unconditional love is not unconditional. It is thus surprising that for Swain empathy and kitchen soups are logically connected with Kantian enlarged 
thinking since regardless of its multiple interpretations it means at least taking perspectives of other people, which as I showed is hardly guaranteed by love and empathy.

The power of Eberle's Agapic Pacifist's ideas or Good Samaritan figure are drawn from the quality of unconditionality of religious convictions. We can present further examples of this power drawn from philosophical writings that point to religion's unconditionality. Waldron (2012) mentions the unconditionality of ban on torture which is expressed in the letter of catholic bishops of the USA and Habermas's (2003) present an example of unconditionality of human dignity, which can be used in coping with the problem of stem cell research.

To approach the matter from a more theoretical perspective. Thomas M. Schmidt (2007: 178) differentiates between sense of unconditionality which is generated in philosophy from transcendence from within and the unconditional sense which is generated by religion. One of the examples of this unconditional sense regenerated by religion is for Habermas the unconditional sense of evil as opposed to moral wrong which can be discussed from different perspectives and thus diminished. When speaking about September, 11 attacks in New York and the use of religious language in its aftermath Habermas writes "The unrestrained way in which this biblical heritage is once more dealt with today shows that we still lack an adequate concept for the semantic difference between what is morally wrong and what is profoundly evil." (2003: 110)

Simone Chambers claims that religion's persistence in the public sphere can be interpreted in two different ways. It is possible that we have as yet not learned to express some normative truth in a secular language: "Under other circumstances, in another time, we might not need religion as a vehicle to express normative truth. In this more fully secularized lifeworld, religion and morality would occupy two separate spheres; differentiation would be complete." (2007: 219) There is also a possibility that the persistence of religion is indicative of the way we experience the world: 
On this reading, religion (or something like it) will always have the power to communicate truth. I call this the Aristotelian interpretation only because on this reading rhetorical power is not due to a cognitive deficit on the part of the hearer. Rhetorical power instead is due to the fact that an utterance truly speaks to, touches, or moves the hearer. (Chambers 2007: 220).

I think it is not a coincidence that Chambers writes in the parenthesis "or something like this" because it is not only religion that possesses e. g. the power of exemplary figure (cf. Cooke: 2011). What I mean is that the excessive focus on religion has made secular exemplary figures invisible: Edward Snowden, Pussy Riot or Occupy Wallstreet have made their mark on the emancipation imagery, however, it is so much more difficult if not impossible for secular examples to attain a level of unconditionality that religion has. Perhaps that is also good. It may be that the burden of pluralism means also the burden of conditionality regardless of whether we talk about religion or secular reasons. Habermas is right to point to the examples where unconditionality servers the good purpose but we must not forget that even a good purpose without politicization can be used for paternalistic measures. Good Samaritan can construct who is worthy of help and in what without asking the most concerned how they want to be cared for. We must also not forget that unconditionality is made use of for clearly illiberal issues for example Catholic Church's act of elevating women who refused to have abortion and died in child labour to the status of sainthood makes a heroic act of sacrificing one's life for one's baby an act which is obligatory.

\section{Politicization}

In this section I would like to show that comprehensive doctrines whether secular or religious ones function in the public sphere in a much similar way and they have a very similar structure. They both may try to block a discussion in the public sphere by drawing on their infallible resources of value and meaning. Whether we want it or not those comprehensive doctrines are present in the public sphere and hardly ever in a pure form. There are different types of religious reasons depending on how external authority functions in them as there are different types of say arguments from moral hazard in 
economics or claims to morality amid moral panics against immigrants where both religious and secular reasons intermingle.

Why is a more realistic description of the public sphere important? First, for critical purposes, it is important not to equate the secular with the accessible or the reasonable otherwise secular doctrines except for scientism directed against religion escape criticism unscathed. It is interesting that the only other secular doctrine that is mentioned besides secularism is Marxism (Boettcher: 2009; Swaine: 2009) but the theorists do not dwell on this doctrine. Neither, should we forget that accessibility of a given reason depends on the background culture of a given society and sometimes it is the religious reasons that are more accessible to the mainstream culture than say feminist reasons that are taken not to be reasons at all.

Furthermore, some theorists (cf. March: 2013; Walhof: 2013) show that religious reasons can be engaged and neither are they so impenetrable nor authoritarian as one might think. However, this seeming impenetrability of reasons leads e. g. Christina Lafont (2007) to argue that there may be religious reasons which absolutely resist any translation and to think otherwise would be to pre-empt a genuine conflict between religious and secular doctrine. In other words, for Lafont there seems to be a pool of impenetrable religious reasons set against a pool of apparently liberal secular reasons. This is hardly the case, for one secular reasons are not reasonable by nature and they may correspond (as in the equivalence) to some of religious reasons as in abortion issues where there are both secular and religious reasons against it. In other words the conflict does not have to run between religious and secular reasons but can cut through many different constellations of reasons.

One of the ways in which the divide between religious and secular citizens can be compounded is by perpetuating the idea that the difference between them is that of heteronomous vs autonomous belief formation. I submit that this does not rescue religion from secularist condemnation of heteronomy. In the same article we discussed earlier, Swaine (2009: 186) divides citizens into autonomous ones who are capable of "unforced choices, considered choosing, and an attitude promoting modifications or 
changes to one's ends, attachments, beliefs, and interests, as appropriate and a selfreflective disposition" and heteronomous ones who fulfill only the first condition, e. i. they can be self-reflective but this is just their capacity and not disposition. One of the aims of Swaine's article is, on the one hand, to rescue religious citizens from the charge that having external authority must inevitably lead to the lack of ethics of citizenship in the public sphere and to show that being autonomous does not guarantee ethical attitude towards fellow citizens.

I submit that not only does Swaine seem to locate excessively the problem of ethics of citizenship in the content of religious beliefs but also amplifies the divide between secular and religious citizens by correlating it with the opposition between autonomous and heteronomous. Firstly, he may argue that the content of our convictions such as respect for others' ways of life and the ideas of equality translate directly into how we respond to politicization of new issues and how we ourselves politicize them. The problem is that the acceptance of broadly understood ideals of equality is nothing controversial. What is interesting is what happens with this ideal at the time of deliberation when something new and unexpected comes up. Since the content of belief is the most important, Swaine chooses a kind of generic religion satisfying liberal requirements to evidence that religious citizens can be ethical. However, he never tells us what happens in case of moral disagreements. Secondly, he is trying to persuade us that autonomous people who are able to revise and fallible can yet be bad deliberators since they can support status quo and be manipulative. He rightly explains the fact that somebody formed his her preferences in an autonomous way is no guarantee of ethics of citizenship in the public sphere. Conversely, he claims that heteronomous citizens can observe ethics of citizenship for example by supplying adequate reasons but it in no way connects with his ideas about love and empathy in politics. There are a number of problems with this description. First of all, the content of one's convictions no matter whether heteronomous or autonomous such as the belief in equality does not really tell us much about what happens with this ideal in the processes of politicization. After all, the ideal of equality was invoked also for racist purposes but 
this does not make him reconsider his division into autonomous and heteronomous people. Not to mention the fact that being secular does not make one autonomous in all aspects of life. For example, one may be autonomous when it comes to abortion but not autonomous when reducing all the social problems to economics. In other words, there need not be such a difference between what Swaine defined as autonomy and heteronomy. Finally, we must be careful about stating which ways of life or reasons do not fulfill liberal conditions regardless of whether we talk about heteronomous or autonomous citizens. At the time of moral disagreements it is heteronomous (religious or others) citizens who can appeal most successfully to the ideal of equality politicizing it in such a way that the ideal of justice is transformed. This successful politicization may universally change the law or can be limited to the laws of exemptions. However, this possible result of politicization cannot be ruled out a priori, otherwise, we will end up with a very conservative conception of public reason.

Finally, it is also possible to present a correct picture of a public sphere with both religious, secular, and other comprehensive doctrines present and politicized in the right way $^{2}$ but fail to account for what kind of normatively demanding account of democratic deliberation makes it actually possible. Walhof's paper (2013) Habermas, same-sex marriage and the problem of religion in public life is not only a critique of deliberative democrats who treat religion as ultimately private but also an attempt to describe public sphere in a more realistic way. He (Walhof 2013: 229-230) argues convincingly that religion is inherently political not only because it address problems of common concern but also because it does so in public arenas. Furthermore, religion enters into dialogue with other comprehensive doctrines and its claims are in principle revisable through deliberation. Moreover, religious or quasi-religious arguments are used by non-religious people as well as religious people are capable of using secular reasons. All this undermines the distinction between religious and non-religious reasons especially correlating with accessible vs inaccessible divide (Walhof 2013: 231-232). Ultimately,

\footnotetext{
${ }^{2}$ I take it that 'the right way' can be defined by ability to make claims that are accessible and revise them in the face of criticism from other citizens. It also means willingness and ability to take other perspectives seriously into account.
} 
according to him (ibid.: 234) the distinction is hardly useful from legitimacy point of view since all citizens' beliefs are articulated and constituted by deliberation.

The problem with Walhof's paper is obviously not that he criticizes Habermas's duty of civility that religious citizens should comply with but that he gives us a picture of religious citizens being able to revise their beliefs but fails to make an explicitly normative case that would actually show how those revisions and open attitude are possible. In other words, his proposal is not so much different from Eberle's (Eberle 2009: 169) who agrees that religious citizens should be able to revise their beliefs in the face of criticisms, however, they should go ahead with their proposal based only on scripture if they are not convinced by secular arguments. The aim of this paper is not to propose a particular democratic procedure that would prevent problems that Eberle or Walhof run into. Rather, its aim is to show that contributions like those take for granted the way religious claims are politicized and revised without going into how revisions is actually possible given the authority of the scripture in a political context.

\section{Conclusion}

The aim of this paper was not to solve a problem of what kind of democratic procedure is best for politicization of religious and other compressive doctrines in the public sphere. Rather, the aim of my contribution was to show a particular tendency in contemporary political theory to rescue religion form liberal condemnation by presenting all the good contributions religion can make to the public sphere. To repeat, I do not disparage the good that those religious contributions may do, rather I want to show how invoking those contributions can replace politicization. Unconditional power of religion can serve a good purpose; however, we must not forget that it can be invoked for good and bad purposes. Even if this great motivational power of religion is used for good purposes such as protection of refugees, it must be accompanied by politics, otherwise, the excessive demands of unconditionality will turn against its plausible moral massage. The same danger comes with judging religion by looking merely at the 
Tomasz JARYMOWICZ, "Comprehensive Doctrines in the Public Sphere - A Case for Politicization",

Kaygl, 18(II)/2019: 289-303.

propositional content of its claims. I submit that such claims need to take part in democratic deliberation to pass the political test of treating others as free and equal. 


\section{REFERENCES}

ARENDT, H. (1998) The Human Condition. The University of Chicago Press.

BOETTCHER, James W. (2009) 'Habermas, religion, and the Ethics of Citizenship', Philosophy Social Criticism 35 (1-2): 215-238

CHAMBERS, Simone (2007) 'How religion speaks to the agnostic: Habermas on the persistent value of religion', Constellations, 14(2): 210-223.

COOKE, Maeve, (2011) 'Translating Truth', Philosophy and Social Criticism 37 (4): 479-491

EBERLE, Christopher J. (2009), 'Basic Human Worth and Religious Restraint', Philosophy and Social Criticism 35 (1-2): 151-181

HABERMAS, Juergen (2003). The future of human nature. Polity Press.

HABERMAS, Jurgen, (2006) 'Religion in the Public Sphere', European Journal of Philosophy 14 (1): 1-25

LAFONT, Christina (2007) 'Religion in the public sphere: remarks on Habermas's conception of public deliberation in postsecular societies', Constellations, 14(2), 239-259.

MARCH, Andrew F. (2013) 'Rethinking Religious Reasons in Public Justification', American Political Science Review 107 (3), pp 523-539.

PETTERSEN, T. (2012) 'Conceptions of care: Altruism, feminism, and mature care', Hypatia 27(2): 366-389.

SCHMIDT, Thomas M. (2007) 'The Semantic Contents of Religious Beliefs and their Secular Translation' in Heimbrock H-G, Scholtz C.P. ed. Religion: immediate experience and the mediacy of research: interdisciplinary studies, concepts and methodology of empirical research in religion. Gottingen: Vandenhoeck und Ruprecht $\mathrm{GmbH}$ and Co.

SWAINE, L. (2009) 'Deliberate and free Heteronomy in the public sphere', Philosophy \& Social Criticism, 35(1-2): 183-213.

TALISSE, Robert (2012) 'Religion, respect and Eberle's Agapic Pacifist', Philosophy \& Social Criticism, 38(3): 313-325.

WALDRON, Jeremy, (2010), 'Two-Way Translation: The Ethics of Engaging with Religious Contributions in Public Deliberation', New York University School of Law, Public Law Research Paper No. 10-84 available at http://papers.ssrn.com/sol3/Papers.cfm?abstract_id=1708113. 
Tomasz JARYMOWICZ, “Comprehensive Doctrines in the Public Sphere - A Case for Politicization",

Kaygt, 18(II)/2019: 289-303.

WALHOF, Darren R. (2013) 'Habermas, same-sex marriage and the problem of religion in public life', Philosophy and Social Criticism, 39(3): 225242. 